\title{
Abdominal Diameter Profiles have Relationship with Insulin Resistance in Obese Female Adolescents
}

\author{
Fillah Fithra Dieny ${ }^{1,2 \star}$, Ria Fitri Setyaningsih ${ }^{1}$, Deny Yudi Fitranti ${ }^{1,2}$, Firdananda Fikri Jauharany ${ }^{1}$, \\ Yehezkiel Dwi Putra ${ }^{1}$, A Fahmy Arif Tsani ${ }^{1,2^{* *}}$
}

\author{
${ }^{1}$ Department of Nutrition Science, Faculty of Medicine, Universitas Diponegoro, Semarang, Central Java, INDONESIA \\ ${ }^{2}$ Center of Nutrition Resaerch, Faculty of Medicine, Universitas Diponegoro, Semarang, Central Java, INDONESIA \\ ${ }^{*}$ Corresponding Author: fillahdieny@gmail.com \\ **Corresponding Author: fahmi_tsani@yahoo.com
}

Citation: Dieny FF, Setyaningsih RF, Fitranti DY, Jauharany FF, Putra YD, Tsani AFA. Abdominal Diameter Profiles have Relationship with Insulin Resistance in Obese Female Adolescents. Electron J Gen Med. 2020;17(5):em219. https://doi.org/10.29333/ejgm/7882

\section{ARTICLE INFO}

Received: 8 Nov. 2019

Accepted: 12 Feb. 2020

\section{ABSTRACT}

Purpose: This study aimed to determine the relationship of abdominal diameter consist of Sagital Abdominal Diameter (SAD), Ratio SAD/Height and Abdominal Diameter Index (ADI) with insulin resistance in obese female adolescents.

Method: This study was conducted in June-August 2019 at Universitas Diponegoro, Central Java. this study used cross sectional design with a total of 120 female students aged 17-21 years and selected using purposive sampling method. Study variables included SAD, SAD/Height, ADI and insulin resistance level. SAD was measured by abdominal caliper, SAD/Height was ratio of SAD divided by height. ADI was ratio of SAD divided by thigh circumference. The value of insulin resistance was obtained from the calculation of homeostasis model assessment insulin resistance (HOMA-IR). Data normality was analyzed by Kolmogorov-smirnov test, all data were not normal distribution so the bivariate test analyzed by Rank spearman test.

Results: As many as $42.5 \%$ subjects had SAD which included at risk and $83.3 \%$ subjects had suffering insulin resistance. There was significant relationship between $S A D$, SAD/Height, $A D I$ with insulin resistance $(S A D$ $(p=0.001), S A D /$ Height $(p<0.001)$ and $A D I(p=0.003)$. In addition, SAD, SAD/Height, ADI were significant relationship with fasting blood glucose ( $S A D(p=0.048), S A D /$ Height $(p=0.022)$ and $A D I(p=0.003)$.

Conclusion: There were significant relationship between SAD, SAD/Height, ADI with insulin resistance and fasting blood glucose in obese adolescent female.

Keywords: Sagittal Abdominal Diameter (SAD), SAD/Height, Abdominal Diameter Index (ADI), insulin resistance

\section{INTRODUCTION}

Obesity is one factor of that cause various diseases such as cardiovaskular disease, hypertension, cancer, and diabetes mellitus. Most countries in Asia have increasing of overweight and obesity prevalence in this last decade. Increased of obesity prevalence does not only occured in adult group but also occured in adolescent group. Indonesia is the one of the countries that have high prevalence of abdominal obesity in the Southeast Asian region (1). The prevalence of visceral/abdominal obesity at age $\geq 15$ years based on Basic Health Research 2013 as many as $26.6 \%$ and increase to $31 \%$ in 2018 (2,3). A study of adolescent in Semarang showed that 46 of 566 adolescents suffering abdominal obesity (4). The prevalence of abdominal obesity in female higher than male, the result data of Basic Health Research 2013 showed that female group who suffering abdominal obesity is $56.3 \%$ while the male group is $43.7 \%$ (5).

Abdominal obesity can reflect excess of visceral fat tissue or subcutaneous or both. Visceral fat contributes to the pathogenesis of diabetes mellitus, glucose intolerance and insulin resistance. Insulin resistance is a impaired condition of glucose absorption that induced by insulin (6). Fat tissue distribution in intraabdominal area caused increasing metabolic such as lypogenesis and lypolysis activity. Lypolysis produce free fatty acids (FFA), FFA from visceral fat brought to the portal circulation and liver. Excessive of FFA secretion from visceral fat through the liver cause toxic effect for example gluconeogenesis and insulin resistance $(6,7)$. Study of 220 obese children and adolescents in Brazil shows that $33.2 \%$ subjects suffering insulin resistance (8). Study of 52 obese adolescents in Semarang also shows that $91.6 \%$ subjects suffering insulin resistance (9).

Excessive of visceral fat tissue in abdominal obesity can measure by Computed Tomography(CT)as gold standard, but measurement of Waist Circumference (WC), andabdominal diameter also can be used as alternative. Abdominal diameter measurement consist of three components, namely Sagittal Abdominal Diameter (SAD), Sagittal Abdominal Diameter/Height (SAD/Height), Abdominal Diameter Index (ADI) (10). SAD can describe the visceral fat size, moreover it can also predicting metabolic syndrome from visceral fat area. SAD is closely related with visceral fat mass than other 


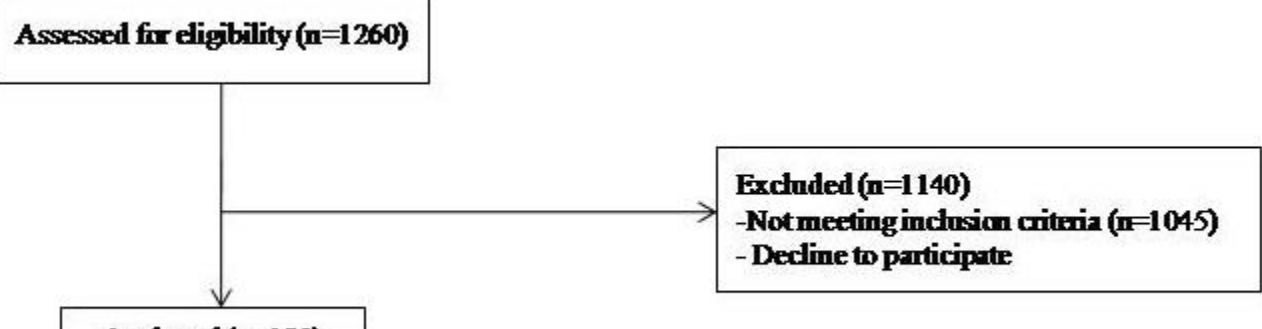

Figure 1. The flow diagram of subject inclusion and exclusion in this research

anthropometric measurements. SAD measured by supine position when subcutaneous fat move to side of waist. SAD measurement at this position reflect size of intraaabdominal fat in antero-posteroir like in $C T$ image measurement. SAD strongly related with glucose intolerance, cardiovascular disease and good indicator for predicting insulin resistance (10-13).

$\mathrm{SAD} /$ Height is derivative of SAD measurement, which is use height as divisor of SAD. SAD/Height is anthropometric indicator that significantly related to visceral fat tissue $(10,14)$. $A D I$ is derivative of $S A D$ measurement divided by thigh circumference. $A D I$ is significantly related to several indicators of metabolic syndrome, and maybe has significant relationship with insulin resistance (15). A study in Brazil also showed that $\mathrm{SAD} /$ Height and ADI is good indicator for measurement visceral fat tissue in women (16). Study on abdominal diameter (SAD, $\mathrm{SAD} /$ Height and ADI) as insulin resistance indicator has not been much done especially in Indonesia. Therefore, based on this background the researchers interest to identifying the relationship of abdominal diameter (SAD, SAD/Height and ADI) with insulin resistance in obese adolescent female.

\section{METHODS}

This study was conducted in June-August 2019 with female student subject at Diponegoro University Semarang. This study was a observational analytic with cross sectional design. As described in Figure 1, of 1260 participants from this study were selected by screening process which obtained 1260 subjects, after that 215 subjects were included to inclusion criteria and selected as many as 120 subjects who involved in this study using purposive sampling method. The inclusion criteria were female student in Diponegoro University Semarang, aged 1721 years, having waist circumference $>80 \mathrm{~cm}$, not pregnant, not consuming alcohol, not consuming drug that can related to glucose and insulin level, willing to fast minimum 8 hours before taking blood sample. The exclusion criteria was the subject resign during the study.This study had received permission from the Health Research Ethics Committe with Number373/EC/KEPK/FK UNDIP/VIII/2019.

The independent variables in this study were abdominal diameter consisting of SAD, SAD/Height, and ADI. SAD measured by abdominal caliper which is manually measurement. Measurement were conducted with supine position, subject relax on the table. One of caliper's arm was placed under the subject (illiac crest) and the other caliper's arm was slowly moving down on subject abdomen with normal breathing (14). SAD categorized as normal if $<19.3 \mathrm{~cm}$ and at
Table 1. Subject characteristic

\begin{tabular}{cccc}
\hline Variable & Min & Max & Median \pm SD \\
\hline Age (year) & 17 & 21 & $19 \pm 0.8$ \\
\hline Weight $(\mathrm{kg})$ & 47.80 & 107.40 & $66.60 \pm 11.38$ \\
\hline Height $(\mathrm{cm})$ & 141.20 & 171.40 & $157.40 \pm 5.44$ \\
\hline Sagittal Abdominal Diameter(cm) & 14.90 & 26.10 & $18.68 \pm 2.12$ \\
\hline $\begin{array}{c}\text { Sagittal Abdominal } \\
\text { Diameter/Height (ratio) }\end{array}$ & 0.09 & 0.17 & $0.12 \pm 0.014$ \\
\hline Abdominal Diameter Index/ADI & 0.03 & 0.56 & $0.32 \pm 0.41$ \\
\hline Fasting blood glucose(mg/dL) & 68.00 & 206.00 & $87.00 \pm 13.15$ \\
\hline Insulin $(\mu \mathrm{U} / \mathrm{mL})$ & 2.71 & 52.60 & $10.82 \pm 6.92$ \\
\hline HOMA-IR & 0.54 & 18.32 & $2.33 \pm 2.09$ \\
\hline & & &
\end{tabular}

risk if $\geq 19.3 \mathrm{~cm}$ (17). SAD/Height was derivative of $S A D$, which is use height (in centimeter) as SAD devisor. ADI was derivative of SAD measurement devided by thigh circumference (in centimeter). The thigh circumference was measured on the right side of the body, at the midpoint between inguinal crease and proximal border on the patella (16).

The dependent variable in this study was insulin resistance. Insulin resistance is a diruption of the biological response to insulin which cause body insulin requirement increase and then resulting hyperinsulinemia to mantain normal glucose level. Insulin resistance level obtained from calculating Homeostasis Model Assessment Insulin Resistance (HOMA-IR), with formula (18):

$$
\text { HOMAIR }=\frac{\text { fasting insulin }\left(\frac{m U}{L}\right) \times \text { fasting glucose }\left(\frac{m m o l}{L}\right)}{22.5}
$$

Cut off the normal value of HOMA-IR in adolescent was $<1.65$ (9). Blood sample of subject was taking by laboratory officer. Before the blood was taken, the subject fasting for 8-12 hours and then blood was taken $5 \mathrm{cc}$.

Univariate data analyze was used to describe the characteristic of each variable in this study. Data normality test analyzed by Kolmogorov-smirnov test. Bivariate data analyzed by Rank spearman test for abnormal data distribution. The purpose of bivariate analysis were to determine relationship of each abdominal diameter variable with insulin resistance.

\section{RESULT}

\section{Subject Characteristic}

Table 1 shows subject characteristic of this study. Age range of subjects were 17-21 years old. The highest fasting blood glucose of subject was $206 \mathrm{mg} / \mathrm{dLwhile}$ the lowest fasting blood glucose was $68 \mathrm{mg} / \mathrm{dL}$. The median in insulin level 
Table 2. Frequency distribution of sagittal abdominal diameter, fasting blood glucose, fasting insulin and HOMA-IR

\begin{tabular}{ccc}
\hline Characteristic & n & $\%$ \\
\hline Sagittal Abdominal Diameter & & \\
\hline No risk & 69 & 57.5 \\
\hline At risk & 51 & 42.5 \\
\hline Normal & \\
\hline High & 117 & 97.5 \\
\hline Fasting Insulin & 3 & 2.5 \\
\hline Normal & & \\
\hline High & 107 & 89.2 \\
\hline HOMA-IR & 13 & 10.8 \\
\hline Normal & & 16.7 \\
\hline Resistance & 20 & 83.3
\end{tabular}

Table 3. Relationship of abdominal diameter with insulin resistance and fasting blood glucose

\begin{tabular}{ccccc}
\hline \multirow{2}{*}{ Variable } & \multicolumn{2}{c}{$\begin{array}{c}\text { Fasting blood } \\
\text { glucose }\end{array}$} & \multicolumn{2}{c}{ HOMA-IR } \\
\cline { 2 - 5 } & $\mathbf{r}$ & $\mathbf{p}$ & $\mathbf{r}$ & $\mathbf{p}$ \\
\hline Sagittal abdominal diameter & 0.181 & 0.048 & 0.297 & 0.001 \\
\hline SAD/Height & 0.209 & 0.022 & 0.345 & $<0.001$ \\
\hline Abdominal diameter index & 0.270 & 0.003 & 0.273 & 0.003 \\
\hline
\end{tabular}

of subject was $0.82 \mu \mathrm{U} / \mathrm{mL}$. The highest HOMA-IR value of subject was 18.32 with median value 2.33 . The median in SAD measurement was $18.68 \mathrm{~cm}$. The highest SAD measurement of subject was $26.10 \mathrm{~cm}$.

Frequency distribution of sagittal abdominal diameter,fasting blood glucose, fasting insulin and HOMA-IR were presented in Table 2. Almost half of the subjects (42.5\%) had SAD that categorized at risk. Majority of subjects (89.2\%) had normal fasting insulin level. Almost of subjects (97.5\%) had normal fasting blood glucose, whereas conversely most of subjects $(83.3 \%)$ had suffering insulin resistance.

\section{Relationship of Abdominal Diameter with Insulin Resistance}

Bivariate analysis in this study used Rank Spearman test. Relationship of abdominal diameter with insulin resistant and fasting blood glucose were presented in Table 3. In this study, we found that SAD,SAD/Height and ADI had significant relationship with insulin resistance and fasting blood glucose $(p<0.05)$, with positive correlation.

\section{DISCUSSION}

The result of this study shows that SAD median was $18.68 \pm 2.12 \mathrm{~cm}$ with minimum value $14.90 \mathrm{~cm}$ and maximum value $26.10 \mathrm{~cm}$. This result similar to study that conducted in Brazil byFeliciano et al.showed that in overweight adolescent the SAD measurement reached $26.3 \mathrm{~cm}$ (19). SAD is indicator that can describe visceral fat size (20). SAD measured by supine position, visceral abdominal fat tend to lift the abdominal wall toward sagittal, abdominal subcutaneous fat pressure the stomach and subcutaneous fat moves to the waist, so SAD can reflect the visceral abdominal fat volume (21). As many as $42.5 \%$ subjects had SAD which categorized at risk. SAD in women closely related with hyperlipidemia, insulin resistance and cardiovaskular risk, moreover it can also be used as a predictor of cardiometabolic risk score (22). The study of children and adolescent in Arab shows that SAD significantly related with the severity of metabolic syndrome components (23).

The result of this study shows that HOMA-IR median was $2.33 \pm 2.09 \mathrm{~cm}$ with minimum value $0.54 \mathrm{~cm}$ and maximum value $18.32 \mathrm{~cm}$. The high score of HOMA-IR similar to González-Zavala et al.'s study that found high score of HOMA-IR in overweight adolescent subjects that reached 18.32 (24). This study showed that the HOMA-IR most of subjects (83.3\%) included in insulin resistance category, however, almost of subjects had normal fasting blood glucose and normal fasting insulin. This result similar to Yi Kung Hye et al.'s study that found high prevalence of insulin resistant in obese adolescent subject was $47.1 \%$ (25). The study of 38 obese adolescent in Semarang also shows similar result with this study. This condition can occur because hyperglycemia is the last part from insulin resistance condition, which is long enough condition of impaired glucose intolerance and or impaired fasting blood glucose. Carbohydrate metabolism in adolescence also still good, so the body can maintaining normal glucose level (26). The high incidence of insulin resistance who suffering by subjects increased the risk of metabolic syndrome, because insulin resistance is a risk factor for metabolic syndrome that first arise (9). The highest HOMA-IR value in the subject was 18.32 . Adolescent group with metabolic syndrome significantly had higher of HOMA-IR. HOMA-IR is indicator that strongly correlated with total and basal insulin. The HOMA-IR mean progressively increase with following sex maturation increase and weight from normal to obese. The study in India shows that the increase of HOMA-IR significantly related with body mass index, moreover there was significant different between HOMA-IR in adolescent with normal nutritional status, overweight and obesity (27).

Bivariate analysis in this study showed that $S A D$, $\mathrm{SAD} /$ Height, and ADI significant related to insulin resistance with positive correlation. A study of 75 overweight and obese adolescent showed that $S A D$ and insulin resistance had significant relationship, with correlation that not much different from this study $(r=0.485)$. The study also showed that SAD described a better correlation with insulin resistance than other anthropometric measurements. SAD can predict insulin resistance because it measures abdominal visceral fat than subcutaneous fat. Abdominal visceral fat also had strongly related with cardio metabolic disease (28). The study of women subject in Brazil comparing SAD with body mass index (BMI), waist circumference (WC), waist to hip ratio (WHR) as resistance insulin indicator, the result show that SAD and BMI was strongest indicator to indicate the occurence of insulin resistance. BMI was widely used to indentify metabolic risk but it can not be used alone, because it can not distinguish muscle adipose tissue or body fat distribution, whereas SAD had reported as a good marker for visceral adipose tissue in various etnic group (21).

In contrast with $S A D$, study about relationship between $\mathrm{SAD} /$ Height ratio and $A D I$ with insulin resistance still limited, but study of 194 subjects in Brazil shows that SAD/Height and $A D I$ had significant related and positive correlation with visceral adipose tissue (16). A study of 1347 subjects in Korea showed that high visceral fat mass and low adiponectin level were correlated with increased risk of insulin resistance and $\beta$ cell dysfunction. Obesity is well known as risk factor for insulin resistance. Abdominal obesity can cause insulin resistance by stimulating metabolic product formation which derived from 
fat, hormone and cytokines. Insulin resistance can cause endothelial dysfunction and insulin signaling pathway changes. Several previous studies show that visceral adipose tissue can inhibit adiponectin secretion. Adiponectin mediates the insulin sensitivity system and glucose homeostasis (29). Insulin resistance is adaptive response of Free Fatty Acid (FFA) increase, and related with visceral adipose tissue level. FFA increase can change the liver, muscle and other tissue metabolism toward lipid deposition and oxidation. Insulin secretion increase offset the glucose capacity decrease. Subcutaneous adipose tissue taking FFA and storing excess caloriesin visceral adipose tissue (30). Excess FFA secretion from visceral fat will be oxidized, stored (lipids droplets) or metabolized to toxic derivatives (DAG and ceramides). Toxic derivatives cause insuline resistance, impaired cell function (lilpotoxicity) or cause apoptosis. Apoptosis in the pancreas cause decrease and impairment of $\beta$ cell capacities to secrete insulin which increase the risk of developing type 2 diabetes mellitus. The consequence of insulin resistance increase is endogenous glucose production by liver and glucose utilization decrease by peripheral tissue. As result are glycemia and insulin pancreas secretion increase, beside that occure hepatic insulin clearance impaired, and causing hyperinsulinemia (31).

This study also showed that significant relationship between abdominal diameter (SAD, SAD/Height, and ADI) with fasting blood glucose level. Abdominal diameter measurement can reflect visceral fat. Visceral/abdominal fat stores are considered as implication of insulin resistance, cardiovascular and other metabolic condition which related to type 2 diabetes mellitus. Excessive visceral fat related with impaired of insulin sensivity. Visceral fat related with impaired glucose regulation, because it is closely related to insulin resistance (32). Lypolysis of visceral fat can cause free circulated of FFA in obese individual. This cause FFA enter to portal vein which can accumulated in the liver and cause impaired of glucose tolerance and insulin homeostasis. Visceral fat tissue and liver fat tissue related with insulin resistance in diabetic patient. A study of 297 subject showed that subject with isolated impaired fasting glucose and isolated impaired glucose tolerance had excess abdominal fat (visceral fat, abdominal subcutaneous fat and liver fat) (33).

\section{CONCLUSION}

As many as $42,5 \%$ subjects had SAD were categorized at risk, while $83,3 \%$ subject had suferring resistance insulin. There were significant relationship between abdominal diameter (SAD, SAD/Height, ADI) with insulin resistance and fasting blood glucose in obese adolescent female, with positive correlation. As it is important to monitor the growth and development of adolescents over time, it is advisable to standardize the use of one measure of body fat location. Considering that abdominal fat, more than total fat, has been associated with cardiometabolic risk, it is recommended the use abdominal diameter measurement (SAD, SAD/Height, ADI)as a measure that reflects the adipose tissue in this region, in the assessment of the nutritional status of adolescents.

\section{ACKNOWLEDGEMENTS}

This research was funded by the "Hibah Penelitian Dasar Unggulan Perguruan Tinggi (PDUPT) 2019, The Ministry of Research, Technology and Higher Education, Indonesia."

\section{REFERENCES}

1. Ramachandran A, Snehalatha C. Rising burden of obesity in Asia. Journal of Obesity, 2010:1-7. https://doi.org/ 10.1155/2010/868573 PMid:20871654 PMCid:PMC2939400

2. Ministry of Health Republic of Indonesia. Riset Kesehatan 2013. Jakarta: Health Research and Development Agency Ministry of Health Republic of Indonesia. 2013.

3. Ministry of Health Republic of Indonesia. Riset Kesehatan Dasar 2018. Jakarta: Health Research and Development AgencyMinistry of Health Republic of Indonesia. 2018.

4. Hanifah NID, Dieny FF. Hubungan Total Asupan Serat, Serat Larut Air (Soluble), Dan Serat Tidak Larut Air (Insoluble) Dengan Kejadian Sindrom Metabolik Pada Remaja Obesitas. Journal of Nutrition College, 2016;5(3):148-55. https://doi.org/10.14710/jnc.v5i3.16385

5. Sudikno S, Syarief H, Dwiriani CM, Riyadi H. Faktor Risiko Obesitas Sentral Pada Orang Dewasa Umur 25-65 Tahun Di Indonesia (Analisis Data Riset Kesehatan Dasar 2013). The Journal of Nutrition and Food Research, 2016;38(2). https://doi.org/10.22435/pgm.v38i2.5540.111-120

6. Ye J. Mechanisms of Insulin Resistance in Obesity. Frontiers of Medicine in China, 2013;7(1):14-24. https://doi.org/10.1007/s11684-013-0262-6 PMid:23471659 PMCid:PMC3936017

7. Westphal SA. Obesity, Abdominal Obesity, and Insulin Resistance. Clinical Cornerstone, 2008;9(1):23-31. https://doi.org/10.1016/S1098-3597(08)60025-3

8. dos Santos Romualdo MC, de Nobrega FJ, Escrivao MAMS. Insulin Resistance in Obese Children and Adolescents. Jornal de Pediatria, 2014;90(6):600-7. https://doi.org/ 10.1016/j.jped.2014.03.005 PMid:25019650

9. Nuraini IS, Sulchan M, Dieny FF. Resistensi Insulin pada Remaja Stunted Obesity Usia 15-18 Tahun di Kota Semarang. Journal of Nutrition College, 2017;6(2):164-71. https://doi.org/10.14710/jnc.v6i2.16906

10. Carneiro Roriz AK, Santana Passos LC, Cunha De Oliveira C, Eickemberg M, De Almeida Moreira P, Barbosa Ramos L. Anthropometric Clinical Indicators in the Assessment of Visceral Obesity: an Update. Nutricion Clinica Dietetica Hospitalaria, 2016;36(2):168-79. https://doi.org/10.12873/ 362carneirororiz

11. Anjana M, Sandeep S, Deepa R, Vimaleswaran KS, Farooq S, Mohan V. Visceral and Central Abdominal Fat and Anthropometry in Relation to Diabetes in Asian Indians. Diabetes Care, 2004;27(12):2948-53. https://doi.org/ 10.2337/diacare.27.12.2948 PMid:15562212

12. Firouzi SA, Tucker LA, LeCheminant JD, Bailey BW. Sagittal abdominal diameter, waist circumference, and BMI as predictors of multiple measures of glucose metabolism: An NHANES investigation of US adults. Journal of Diabetes Research, 2018:1-14. https://doi.org/10.1155/2018/ 3604108 PMid:30018985 PMCid:PMC6029495 
13. Gletsu-Miller N, Kahn HS, Gasevic D, Liang Z, Frediani JK, Torres WE, et al. Sagittal abdominal diameter and visceral adiposity: Correlates of beta-cell function and dysglycemia in severely obese women. Obesity Surgery, 2013;23(7):87481. https://doi.org/10.1007/s11695-013-0874-6 PMid:23408092 PMCid:PMC3750719

14. Khan HS, Rissanen H, Bullard KM, Knekt P. The Population Distribution of the Sagittal Abdominal Diameter (SAD) and $\mathrm{SAD} /$ height Ratio Among Finnish Adults. Clinical Obesity, 2014;4(6):333-41. https://doi.org/10.1016/j.physbeh.2017. 03.040 PMid:28363838 PMCid:PMC5510739

15. Ehrlich AC, Smith DA. Abdominal Diameter Index and 12year Cardiovascular Disease Incidence in Male Bridge and Tunnel Workers. International Journal of Obesity, 2011;35(3):409-15. https://doi.org/10.1038/ijo.2010.143 PMid:20714330

16. Roriz AKC, Passos L, Oliveira C, Eickemberg M, Moreira P, Ramos L. Discriminatory Power of Indicators Predictors of Visceral Adiposity Evaluated by Computed Tomography in Adults and Elderly Individual. Nutricion Hospitalaria, 2014;29(6):1401-7. https://doi.org/10.3305/nh.2014.29.6. 7185

17. Sampaio LR, Simões EJ, Assis AMO, Ramos LR. Validity and reliability of the sagittal abdominal diameter as a predictor of visceral abdominal fat. Arquivos Brasileiros de Endocrinologia e Metabologia, 2007;51(6):980-6. https://doi.org/10.1590/s0004-27302007000600013 PMid:17934666

18. Matthews DR, Hosker JP, Rudenski AS, Naylor BA, Treacher DF, Turner RC. Homeostasis model assessment: insulin resistance and beta-cell function from fasting plasma glucose and insulin concentrations in man. Diabetalogia, 1985;28:412-9. https://doi.org/10.1007/BF00280883 PMid:3899825

19. Pereira PF, Serrano HMS, Carvalho GQ, Ribeiro SMR, et al. Measurements of body fat distribution: assessment of collinearity with body mass, adiposity and height in female adolescents. Revista Paulista de Pediatria, 2015;33(1):6371. https://doi.org/10.1016/S2359-3482(15)30032-4

20. Stokic E, Srdic B, Brtka V, Tomic-Nagalic D. Sagittal Abdominal Diameter as the Anthropometric Measure of Cardiovascular Risk, 2012:319-340. https://doi.org/ 10.5772/31677

21. Vasques ACJ, Cassani RSL, Forti ACe, Viiela BS, Pareja JC, Tambascia MA, et al. Sagittal Abdominal Diameter as a Surrogate Marker of Insulin Resistance in an Admixtured Population - Brazilian Metabolic Syndrome Study (BRAMS). PLOS ONE, 2015;2:1-13. https://doi.org/10.1371/ journal.pone.0125365 PMid:25951458 PMCid:PMC4423830

22. Riserus U, Faire Ude, Berglund L, Hellenius M-L. Sagittal Abdominal Diameter as a Screening Tool in Clinical Research: Cutoffs for Cardiometabolic Risk. Journal of Obesity, 2010:1-7. https://doi.org/10.1155/2010/757939 PMid:20798888 PMCid:PMC2925288

23. Al-attas OS, Al-daghri NM, Alokail MS, Alkharfy KM, Draz H, Yakout $\mathrm{S}$, et al. Association of body mass index, sagittal abdominal diameter and waist-hip ratio with cardiometabolic risk factors and adipocytokines in Arab children and adolescents. BMC Pediatrics, 2012;12(119):16. https://doi.org/10.1186/1471-2431-12-119 PMid:22871266 PMCid:PMC3470957
24. González-Zavala MA, Velasco-Morales A, Terrazas-Flores JJ, de la Cruz-Galiciaae MG. Levels of insulin and HOMA-IR in adolescents in Saltillo, Coahuila, Mexico. Medicina Universtaria, 2015;17(67):80-7. https://doi.org/10.1016/ j.rmu.2015.02.004

25. Yi KH, Hwang JS, Kim EY, Lee SH, Kim DH, Lim SJ. Prevalence of insulin resistance and cardiometabolic risk in Korean children and adolescents: A population-based study. Diabetes Research and Clinical Practice, 2014;103(1):106-13. https://doi.org/10.1016/j.diabres.2013 .10.021 PMid:24290751

26. Ramadhan NR, Wijayanti HS. Dietary Acid Load, Keseimbangan Asam Basa Tubuh dan Resistensi Insulin pada Remaja Obesitas. Journal of Nutrition College, 2017;6(1):69-75. https://doi.org/10.14710/jnc.v6i1.16895

27. Singh Y, Garg MK, Tandon N, Marwaha RK. A Study of Insulin Resistance by HOMA-IR and its Cut-off Value to Identify Metabolic Syndrome in Urban Indian Adolescents Yashpal. Journal of Clinical Research in Pediatric Endocrinology, 2013;5(4):245-51. https://doi.org/10.4274/Jcrpe.1127 PMid:24379034 PMCid:PMC3890224

28. Krishnappa SK, Yashoda HT, Boraiah G, Vishwa S. Sagittal Abdominal Diameter to Measure Visceral Adipose Tissue in Overweight or Obese Adolescent Children and Its Role as A Marker of Insulin Resistance. Journall of Clinical and Diagnostic Research, 2015;9(11):9-12. https://doi.org/ 10.7860/JCDR/2015/15971.6742 PMid:26673888 PMCid:PMC4668495

29. Moon HU, Ha KH, Han SJ, Kim HJ, Kim DJ. The Association of Adiponectin and Visceral Fat with Insulin Resistance and $\beta$-Cell Dysfunction. Journal of Korean Medical Science, 2019;34(1):1-12. https://doi.org/10.3346/jkms.2019.34.e7 PMid:30618514 PMCid:PMC6318440

30. Donohoe CL, Doyle SL, Reynolds JV. Visceral Adiposity, Insulin Resistance and Cancer Risk. Diebetoogy \& Metabolic Syndrome, 2011;12(3):1-13. https://doi.org/10.1186/17585996-3-12 PMid:21696633 PMCid:PMC3145556

31. Castro AVB, Koika CM, Kim SP, Bergman RN. Obesity, Insulin Resistence and Cormobidities - Mechanisms of Association. Arq Bras Endocrinol Metabol, 2015;58(6):6009. https://doi.org/10.1159/000398850

32. Kantartzis K, MacHann J, Schick F, Fritsche A, Häring HU, Stefan N. The Impact of Liver Fat VS Visceral Fat in Determining Categories of Prediabetes. Diabetologia, 2010;53(5):882-9. https://doi.org/10.1007/s00125-010-166 3-6 PMid:20099057

33. Borel AL, Nazare JA, Smith J, Aschner P, Barter P, Van Gaal $L$, et al. Visceral, subcutaneous abdominal adiposity and liver fat content distribution in normal glucose tolerance, impaired fasting glucose and/or impaired glucose tolerance. International Journal of Obesity, 2015;39(3):495501. https://doi.org/10.1038/ijo.2014.163 PMid:25179244 